\title{
Some Effects of Oil on the Physical and Chemical Characteristics of Wet Tundra Soils
}

\author{
K. R. EVERETT
}

\begin{abstract}
Crude hydrocarbons were added to the surface of wet tundra soils at Barrow, Alaska at volumes of 5 and $121 / \mathrm{m}^{2}$. Physical and chemical effects in the soil were followed for three years. Soils treated with $51 / \mathrm{m}^{2}$ had their chemical and physical properties little altered. Those treated with $12 \mathrm{l} / \mathrm{m}^{2}$ recorded an increase in seasonal thaw, an increase in organic carbon and an increase in available phosphorus. Soil pH shifted toward neutrality. Decreases occurred in water infiltration rate and in plant available cations $(\mathrm{Ca}, \mathrm{Mg}, \mathrm{K})$. Soil moisture, bulk density, shrinkage percent and total sulphur content appeared unaffected.
\end{abstract}

RESUME. A Barrow en Alaska, du pétrole brut a été répandu en surface sur des sols de toundra humide, aux taux de 5 et 12 litres au $\mathrm{m}^{2}$. Pendant trois ans, on a suivi les conséquences physiques et chimiques dans le sol. Au taux de $5 \mathrm{litres} / \mathrm{m}^{2}$, les sols traités ont eu leurs propriétés chimiques et physiques peu altérées. Les sols traités sur la base de 12 litres $/ \mathrm{m}^{2}$ ont enregistré un accroissement du dégel saisonnier et un accroissement du carbone organique et du phosphore disponible. Le pH du sol est devenu neutre. Le rendement d'infiltration d'eau décroissait comme celui des cations de plantes disponibles ( $\mathrm{Ca}, \mathrm{Mg}, \mathrm{K})$. L'humidité du sol, sa densité de fmasse, son pourcentage de contraction, et le contenu total en soufre apparaissait sans changement.

Traduit par Alain de Vendigies, Aquitaine Co. of Canada Ltd.

\section{INTRODUCTION}

Investigations on the interaction between hydrocarbons and the soil environment were relatively few until the beginning of this decade. One of the earliest was that of Carr (1919) and involved an oil spill resulting from a pipeline break. Subsequent studies have dealt mostly with crude hydrocarbons as potential agricultural amendments used to stimulate crop response through increased nitrification (Harper, 1939; Abdalla and Hocker, 1963; Endigarova, 1963). Other investigators have detailed the interaction between hydrocarbon gases and the soil, again as these affected crop response through the stimulation or suppression of microbial mineralization of nitrogen and phosphorous, Shollenberger (1930 and Plice (1948).

In the late 1960's and throughout the 1970's research on the interaction of hydrocarbons and the environment has been intense, stimulated by the release of enormous quantities of petroleum hydrocarbons into the marine and littoral environments as a result of tanker accidents and in response to the envisioned release of equally large quantities in the terrestrial environment from pipeline breaks. For the most part, the terrestrial studies have centered on boreal or northern grassland environments (e.g., Hutchinson and Helleburt, 1974; Mackay, 1975) and have addressed the problems of toxicity and response of the natural vegetation to crude oil spills or have investigated methods of reclamation, specifically fertilization (to stimulate microbial degradation of the hydrocarbon) and revegetation (Nyborg and McGill, 1975; Rowall, 1975; Toogood et al., 1977).

"Contribution No. 367 of the Institute of Polar Studies, the Ohio State University, Columbus, Ohio 43210 
It was not until 1971 that research was undertaken in the Arctic. At this time an experiment was conducted at Barrow, Alaska involving unrefined Prudhoe Bay oil (Deneke et al., 1975). The following year studies were begun on the effects of oil on the flora of the Canadian Northwest Territories at Norman Wells (Hutchinson, 1973). At Barrow the oil was applied at different volumes directly on the plant-soil surface (sedge meadow) and to the ground surface (not affecting the foliar components). As the primary emphasis was to document vegetation response, no direct effort was made to examine the below ground component, i.e., changes in the physical and chemical characteristics of the soil material or the soil flora (or fauna).

In July 1975 a three year program was initiated at Barrow to study the reactions of portions of the below ground ecosystem to unrefined hydrocarbons applied at the surface. The Barrow area (International Biological Program, Tundra Biome study site) was chosen because of the extensive data base generated during the preceding IBP years and the proximity of the site to the facilities of Naval Arctic Research Laboratory.

The main study dealt with the response of the soil microflora to hydrocarbon impact, reported elsewhere in this volume and the response of the soil itself to the hydrocarbons. This second aspect of the study was directed toward answering the question (in context of the microorganisms) of what affect(s) the crude hydrocarbons have on the physical characteristics of the soil and on the inorganic nutrient chemistry of the soil matrix and soil solution.

\section{SITE CHARACTERISTICS}

The experimental sites at Barrow consisted of the elements of a well developed low centered polygon, i.e., rim, basin and trough and a series of high centered polygons. This group of features is typical of large expanses of the arctic coastal plain and represents a wide range in soil characteristics including moisture. Some significant soil edaphic characteristics are summarized for each site in Table 1. Figure 1 depicts the variability in soil morphology encountered on the study sites. At a minimum, similar variability can reasonably be expected at any given site and, in particular, for this study all analytical data should be interpreted with reference to Figure 1. Brown and Veum (1974); Gersper et al. (1974); Everett (1974) and Brown et al. (in press) should be consulted for detailed discussions of the Barrow landscape and soils.

\section{METHODS}

On 26 June 1975 two experimental plots and a control plot were designated on each of the three elements of the polygon i.e., rim, trough and center. The plots are basically rectangular, but because of problems associated with choosing uniform representations they range in size from 6.3 to $14 \mathrm{~m}^{2}$. Those to receive oil treatment were surrounded by heavy plastic sheeting, depressed below the surface to frost - and extended above the surface $10 \mathrm{~cm}$ or so, to prevent contamination of the control and/or adjacent plots (Fig. 2). Of the three comparable high centered polygons that were chosen, one was 
TABLE 1. Selected ranges for some edaphic characters for soils characteristic of the oil spill plots at Barrow, Alaska. Unless noted data are for the 0-10 cm depth interval and have been rounded. Sources: Brown and Veum 1974; Everett, 1974; Everett, unpublished; Barél and Barsdate, 1974.

\begin{tabular}{|c|c|c|c|c|c|c|c|c|c|c|c|c|}
\hline \multirow{2}{*}{ Site } & \multirow{2}{*}{$\begin{array}{l}\text { Maximum thaw } \\
\text { depth } \\
\text { in } \mathrm{cm}\end{array}$} & \multirow{2}{*}{$\begin{array}{l}\text { Avg. summer } \\
\text { temp. in } 0^{\circ} \mathrm{C} \\
7.5 \mathrm{~cm}\end{array}$} & \multirow{2}{*}{$\begin{array}{l}\text { Moisture } \\
\text { Vol. \% }\end{array}$} & \multirow{2}{*}{$\begin{array}{l}\text { Shrinkage } \\
\text { at } 105^{\circ} \mathrm{C}\end{array}$} & \multirow{2}{*}{$\begin{array}{c}\text { Sand-Silt } \\
\text { ratio }\end{array}$} & \multirow{2}{*}{$\stackrel{\%}{\%}$} & \multirow{2}{*}{$\underset{1: 5}{\mathrm{pH}}$} & \multicolumn{3}{|c|}{$\begin{array}{l}\text { Exchangeable Cations } \\
\text { in Meq } / 100 \mathrm{~g}\end{array}$} & \multirow{2}{*}{$\begin{array}{l}\text { Available } \\
\text { in } \mu \mathrm{g} / \mathrm{g}\end{array}$} & \multirow{2}{*}{$\begin{array}{l}\text { Total } \\
\text { S (\%) }\end{array}$} \\
\hline & & & & & & & & $\mathrm{Ca}$ & Mg & $\mathbf{K}$ & & \\
\hline Basins & $25-37$ & 7.7 & $(9)^{*} 55-91$ & $26-71$ & $0.17-0.35$ & $36-49$ & $4.6-5.8$ & $12-16$ & $7-12$ & $0.2-2$ & $0.6-7.4$ & $.02-0.3$ \\
\hline Rims & $24-35$ & 7.3 & $39-81$ & $15-57$ & $0.12-11.2$ & $15-43$ & $3.9-5.8$ & $6-23$ & $5-15$ & $0.1-1$ & $0.7-34.5$ & $.04-0.2$ \\
\hline Troughs & $23-36$ & 8.0 & $(13) * 46-88$ & $16-60$ & $0.22-0.54$ & $21-54$ & $5.0-6.0$ & $10-36$ & $7-20$ & $0.2-4$ & $0.2-63.1$ & $0.1-0.4$ \\
\hline High & & & & & & & & & & & & \\
\hline Centers & $22-36$ & No data & $15-66$ & $10-54$ & 0.37 & $19-29$ & $3.9-5.0$ & $3-10$ & $1-6$ & $0.3-1$ & $0.2-16.8$ & $.01-0.1$ \\
\hline
\end{tabular}

* Values recorded in 1977 


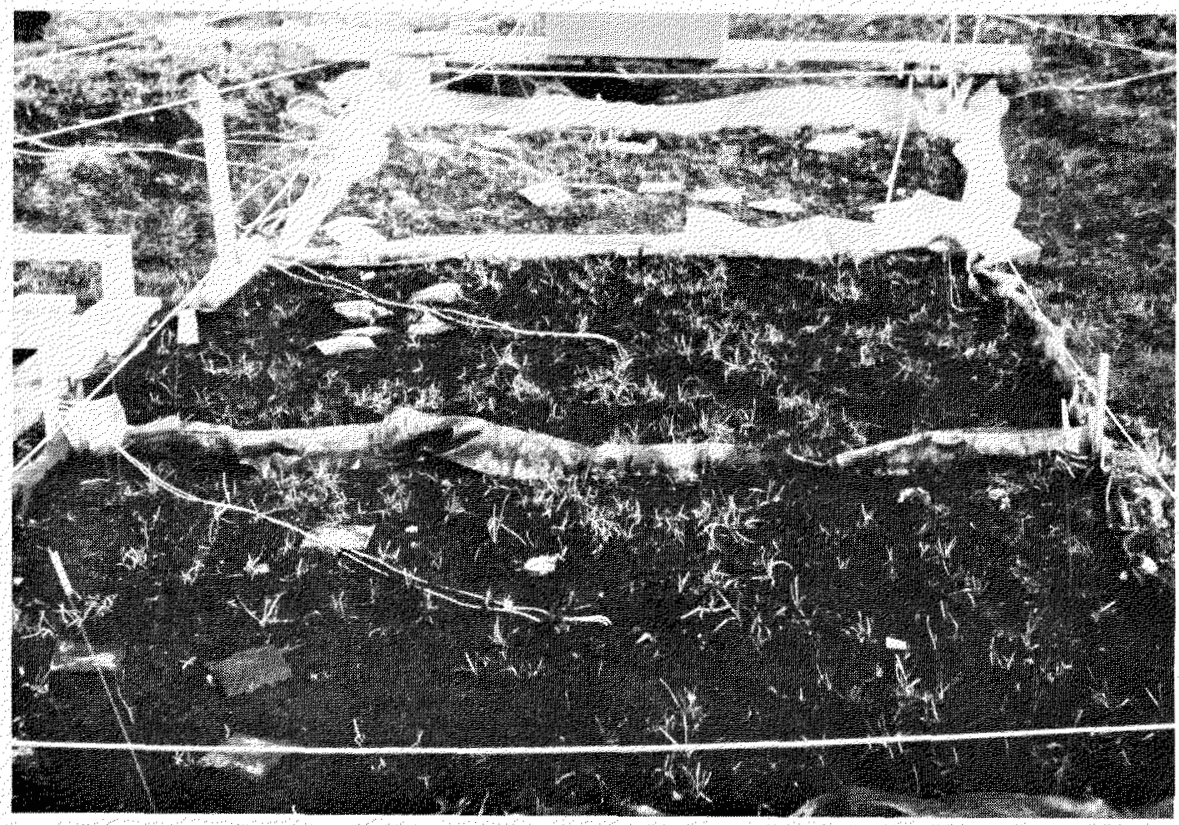

FIG. 2. View of the basin (center) of the low centered polygon showing from foreground to background $12 \mathrm{l} / \mathrm{m}^{2}, 5 \mathrm{l} / \mathrm{m}^{2}$ oil treatment and control plot. Thermister cables lead away from plot centers. Light colored squares are litter decomposition bags. Plastic sheeting separates plots.

designated as a control and the other two designated for oil treatment. Plot types and designations are summarized in Table 2.

Prudhoe Bay crude oil was applied at volumes of $5 \mathrm{l} / \mathrm{m}^{2}$ and $121 / \mathrm{m}^{2}$ to plots at each site. The choice of volumes was governed to a large extent by those used at the USA CRREL sites in 1971 (Deneke, 1975). If resampling of these sites was to be done or comparisons made, the volumes applied would be comparable. Also, the oil volumes are generally comparable to those used by some other investigators (W. M. Mitchell, pers. comm.), and are within the range of small and medium oil spills reported in Alberta by Mackay and Mohtadi (1975).

TABLE 2

\begin{tabular}{llll}
\multicolumn{3}{c}{ Designations } \\
\hline \multicolumn{1}{c}{ Plot Type } & Control & $\begin{array}{c}51 / \mathrm{m}^{2} \\
(.03 \mathrm{bbl})\end{array}$ & $\begin{array}{c}121 / \mathrm{m}^{2} \\
(0.076 \mathrm{bbl})\end{array}$ \\
\hline High Center Polygon & HCC & HC5 & HC12 \\
Low Center Polygon Center & LCBC & LCB5 & LCG12 \\
Low Center Polygon Rim & LCRC & LCR5 & LCR12 \\
Low Center Polygon Trough & LCTC & LCT5 & LCT12 \\
\hline
\end{tabular}


Application of the oil was through a perforated ceramic plate to ensure even coverage of the surface. At the rate of $51 / \mathrm{m}^{2}$ the vegetation or the organic soil surface soaked up all of the oil and no runoff or pooling occurred. Following treatment at the $12 \mathrm{l} / \mathrm{m}^{2}$ volume a considerable amount of oil remained on the surface of the plots. This was especially evident in the low centered basins and troughs (the troughs were saturated to the surface or contained shallow standing water). The plastic barriers adequately contained the oil.

Sampling was begun the day following oil treatment. Four $8 \mathrm{~cm}$ diameter cores were taken to a depth of 10 to $15 \mathrm{~cm}$ and $10 \mathrm{~cm}$ apart at each plot $(5$ cores were taken in subsequent years). Each core was evaluated for its morphological characteristics (data used to construct Fig. 1 and similar figures for each plot). Two cores were used for physical-chemical analyses. The analyses were performed on $0-2,2-4$ and $4-6$ and $6-8 \mathrm{~cm}$ segments (in subsequent years the last two segments were combined). This procedure was repeated at bi-weekly intervals in 1975. Logistic constraints forced curtailment of the schedule in subsequent years.

The following physical analyses were conducted: 1) Soil moisture by volume after drying for 24 hours at $105{ }^{\circ} \mathrm{C}$; 2) Dry and wet weight bulk densities; and 3) Shrinkage.

Analytical methods for chemical characteristics were for the most part those employed for mineral soils: 1) Percent organic carbon determined by dry combustion at $925^{\circ} \mathrm{C}$ in a Lindburg chamber; 2) Soil reaction in a $1: 5$ soil-water mixture with a Beckman Model Battery-operated glass electrode meter (1975) and a Beckman Expandomatic glass electrode meter (1976-1977); 3) Exchangeable calcium, magnesium and potassium determined by atomic absorption spectrophotometry on $1 \mathrm{~N} \mathrm{NH}_{4} \mathrm{OAC}$ leachate; 4) Available phosphorus (1976-1977) by the Bray method using ammonium floride as the extractant and shaking 15 minutes; 5) Total soil sulfur determined by titration with a semi-automatic Leco titrator after ignition to $1500{ }^{\circ} \mathrm{C}$ in an induction furnace. Applying these methods to organic soils (or mineral soils) saturated with hydrocarbons is a problem e.g., determination of exchangeable cations and phosphorus was difficult by these methods. The approach has been to analyze the samples with the hydrocarbons present. Another method using chloroform extraction of the hydrocarbon prior to soil analysis appears to offer an alternative for future studies (McFadden et al., 1977).

In addition to the analyses outlined above, an attempt was made to determine the effect crude oil has on water infiltration rates immediately after application (rates up to $60 \mathrm{l} / \mathrm{m}^{2}$ were used). The oil was applied in a plastic cylinder $8 \mathrm{~cm}$ in diameter to polygon rim and basin plots similar to, but separate from, those designated as experimental plots. Water infiltration using a $10 \mathrm{~cm}$ falling head was made 24 hours and 8 days after oil application.

The progression of seasonal thaw was measured at weekly intervals by probing 10 times in each of the 12 plots. 
TABLE 3. Significance of hydrocarbon impact on selected soil physical and chemical characters for all plots

\begin{tabular}{|l|c|cc|}
\hline Variable & Effect + & \multicolumn{2}{|c|}{ Significance Level } \\
\hline & & & \\
& & 1975 & \\
& & 1976 \\
\hline Soil Moisture, Vol. \% & $(1)$ & .0074 & NS \\
& $(2)$ & NS & NS \\
\hline Dry weight bulk & $(1)$ & NS & ND \\
density g/cm & & .0041 & ND \\
\hline Thaw depth & $(2)$ & .0001 & .0001 \\
& $(1)$ & .0012 & .0002 \\
\hline Exchangeable $\mathrm{K}$ & $(2)$ & NS & .0001 \\
in meq/100 g & $(1)$ & NS & .0001 \\
\hline Exchangeable Mg & $(2)$ & ND & .0001 \\
in meq/100 g & $(1)$ & ND & .0015 \\
\hline Exchangeable Ca & $(2)$ & .0001 & .0001 \\
in meq/100 g & $(1)$ & NS & .0001 \\
\hline Total sulfur, & $(2)$ & .0079 & NS \\
in \% & $(1)$ & NS & NS \\
\hline Organic carbon & $(2)$ & ND & .0090 \\
& $(1)$ & .0030 & .0001 \\
\hline pH & $(2)$ & NS & .0006 \\
\hline Available Phosphorus & $(1)$ & .0005 & .0001 \\
& $(2)$ & .0001 & .0102 \\
\hline
\end{tabular}

Statistical analyses by Margaret A. Chmielewski

+ (1) Control vs $51 / \mathrm{m}^{2}$ and $121 / \mathrm{m}^{2}$

(2) $5.1 / \mathrm{m}^{2}$ vs $121 / \mathrm{m}^{2}$

$\mathrm{NS}=$ not significant

$\mathrm{ND}=$ not determined 


\section{RESULTS AND DISCUSSION}

The data for all variables measured are presented in the Appendix as absolute ranges for the three summers of record. In Table 3 significance levels are summarized for each variable for the two oil treatments.

It is obvious that crude oil applied in this experiment had little effect on the measured physical parameters. However the preliminary investigation of water infiltration rates (hydraulic conductivity generally) indicated that soil texture and structure together with the volume of crude oil applied combined to reduce subsequent (24 hours and 8 days) water infiltration (Fig. 3). Similar

Oil Infiltration 20 July, 1975

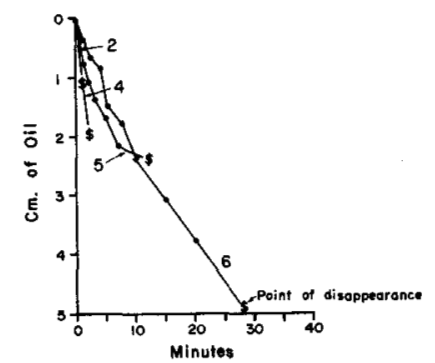

No.I Control

No. $210 \mathrm{t} . / \mathrm{m}^{2}(\mathrm{~m} / / 16 \mathrm{bbl}$.)

No.4 $20 \mathrm{l} . / \mathrm{m}^{2}(-1 / 1 / 8$ bbl.)

No.5 $401 . / \mathrm{m}^{2} .(-1 / 4 \mathrm{bbl}$.)

No.6 $601 . / \mathrm{m}^{2} \cdot(-1 / 3 \mathrm{bbl}$.
Avg. moi.(d.w.) $28.2 \%$

Avg. bd. (wot) $0.55 \mathrm{~g} / \mathrm{cm}^{3}$

Avg. bd. (dry) $0.16 \mathrm{~g} / \mathrm{cm}^{3}$

Temp. of $3 \mathrm{~cm} .=12^{\circ} \mathrm{C}$.

Permatrost $=16.3 \mathrm{~cm}$.

$\mathrm{H}_{2} \mathrm{O}$ Infiltration 21 July, 1975

$\mathrm{H}_{2} \mathrm{O}$ Infiltration $28 \mathrm{Ju}$ y, 1975
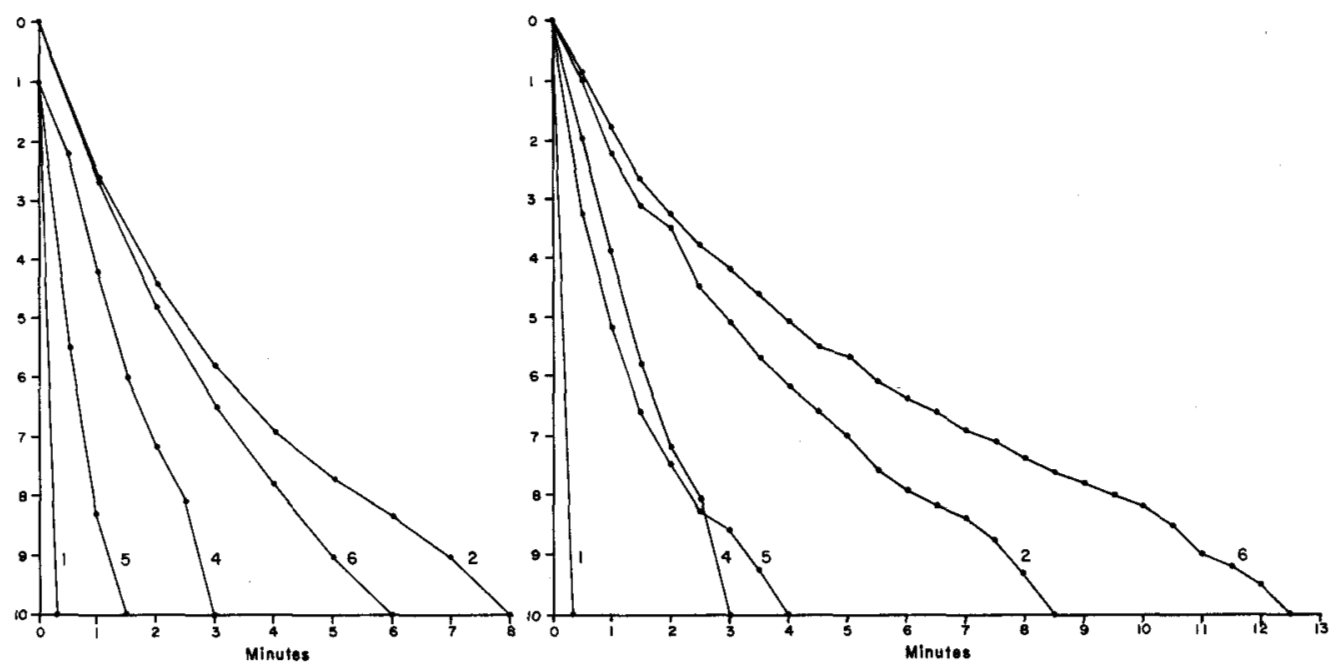

FIG 3. Comparative infiltration (intake) rates for crude oil and water on a polygon rim soil. Barrow, Alaska. 

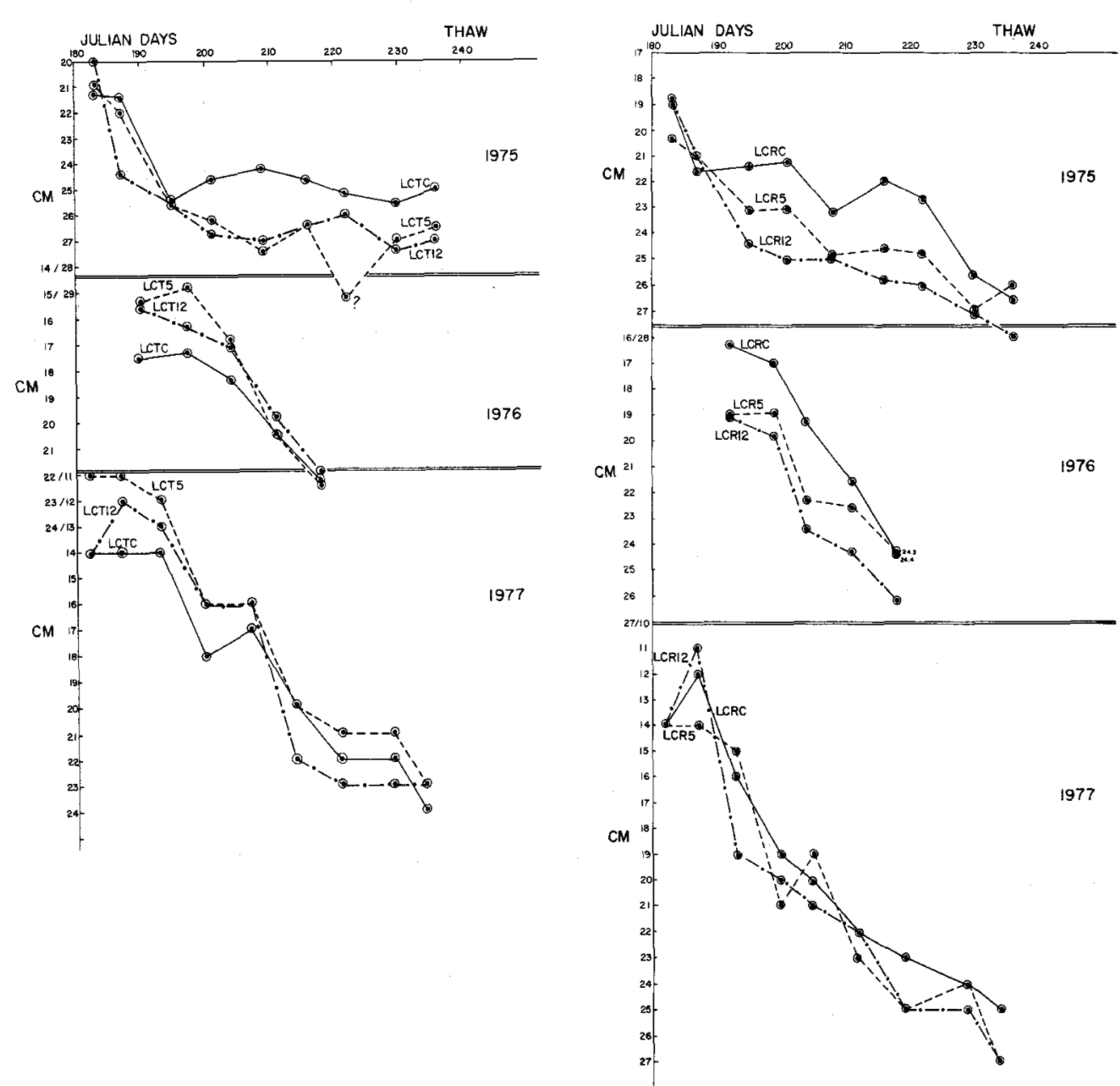

FIG. 4. Cumulative seasonal thaw penetration curves for low centered polygon trough plots (A) and rim plots (B).

results were recorded by Toogood (1977) in mineral soils. He attributes this to a decrease in wetability (not measured in this study) resulting from the formation of hydrophobic films on soil particles.

Increase in seasonal thaw although not directly a physical characteristic of the soil is clearly affected by the addition of crude oil (Table 3). The progression of thaw for two plots is shown in Figure 4. The difference in steepness in the sets of curves between 1975 and the two following years reflects the significant difference in climate among the years. It is also apparent in Figure 4 that the effect of the oil on thaw depth (through elevated soil temperature) is diminishing rapidly with time as vegetation re-establishes (mostly moss Polytrichum juniperinum Hedw.) and as the oil decomposes. 
Changes in chemical characteristics, especially exchangeable ions, as a result of hydrocarbon addition should not be viewed only against plot (and sample) morphology (Fig. 1), but against the seasonal dynamics of these ions in the soil, i.e., their response to vegetation demand. In general, ions will be most abundant in soil solution or on the exchange complex in early summer and decline as vegetation reaches its maximum productivity. Concentrations again increase after peak seasonal demand through leaching of senescent and/or dead tissue. This pattern has been demonstrated in the Barrow tundra (Gersper, 1974) and in this study (see Miller annual reports 1975-6 and 1976-7).

In the unperturbed system the individual plots differ significantly from one another in both the distribution and absolute values for a given variable (see Appendix) and in most cases there is a decrease in the absolute values for a variable as depth increases; e.g., there is a significant reduction in available calcium with depth at least in the upper $8 \mathrm{~cm}$. In addition the high centered polygon site differs significantly for most variables from the plots of the low centered polygon site. Within the low centered polygon the trough element stands out from the rim and center by displaying the widest range in the measured variables.

With regard to hydrocarbon impact the pattern outlined above persists generally but has overprinted the significant affects of that impact. Nowhere is this more obvious than with the exchangeable cations. It is postulated that the considerable reduction in the availability of these ions has resulted from a physical blockage of the exchange sites on the organic and clay mineral components by the hydrocarbon residues. However, there probably has not been a reduction of the total amount of these ions in the soil-water system (although this was not determined). The effect of the reduction in cation availability occurs at both levels of the simulated spill but is less dramatic at the $51 / \mathrm{m}^{2}$ treatment. Also, it is generally confined to the upper $6 \mathrm{~cm}$ at all plots (see Appendix). The pattern of reduction developed the first year and has persisted. Because the hydrocarbon residues can be hydrophobic the blockage will probably continue for some time. The presence or absence of an effect on vegetation depends upon its demands for a particular ion. It is possible that seasonal demand for a certain ion may deplete it in the soil solution and that it will not be replenished from the exchange complex. Thus, nutrient stress could develop in some plants as a result of oil.

The pattern of hydrocarbon influence on soil reaction is at least as variable as the soil reaction itself (see Appendix). However, as shown in Table 3 a significant relationship exists between the presence of hydrocarbon and $\mathrm{pH}$. These data give the impression of broadening the $\mathrm{pH}$ range generally (except for the polygon rim plots) and of shifting it toward neutrality. This trend has been observed in gassed mineral soils (Ellis and Adams, 1961) and in oil-treated mineral soils (Toogood et al., 1977).

Table 3 and the Appendix show that organic carbon has changed on all plots with respect to the control. With the exception of the trough plots the increase (or in some examples an apparent decrease) took place in 1975. The increase 
in the trough plot was delayed until 1976 for it was in that year that the weathered hydrocarbons were let down onto and into the surface as the troughs dried. The apparent depression of organic carbon may be explained by site inhomogeneity i.e., samples collected on any one of the sample dates in 1976 encountered materials with lower natural organic carbon values than found in the control.

Sulfur compounds in crude oil are either insoluble in water or are nonreactive. They may occur as organic compounds, as sulfates or in the elemental form. Currently little is known concerning their environmental significance (Mackay and Phillips, 1974). It is tentatively concluded from the analyses presented in Table 3 that total sulfur is unaffected by the addition of crude hydrocarbons. This in spite of the fact that Prudhoe Bay crude oil has a weight percent sulfur of 0.95 (Rickwood, 1970).

Phosphorus is limiting to plant growth in the Barrow tundra and is a sensitive index of biological demand and should be significantly affected by the addition of crude oil. Labile (available) phosphorus is shown to be significantly affected but not to the degree anticipated (Table 3). A very marked increase in phosphorus availability was observed however, between 1976 and 1977 especially at the high end of the range of values (see Appendix). Concentrations of phosphorus in 1976 were generally similar to those obtained by Barèl and Barsdate (1974). This was true for all plots and was superimposed on normal seasonal fluctuations in $\mathrm{P}$ as well as on normal plot differences e.g., trough areas show the highest labile $P$ levels (Barèl and Barsdate, 1974). Data for both 1976 and 1977 were comparable since both years were relatively dry and warm and climatic conditions in the surface soil horizons were conducive to microbial decomposition of organic materials and release of phosphorus. The increased concentrations of $P$ in 1977 cannot however, be attributed to an increase in microbial activity because in the plots receiving oil it was reduced (in 1977) to 20 to $60 \%$ of the 1976 levels (Atlas, pers. comm.).

As suggested by Adams and Ellis (1960), the increased phosphorus levels may result from release of $P$ from iron phosphates that have been made more soluble in a soil system rendered anoxic by elevated microbial populations. In the Barrow soils inorganic phosphorus is extremely low (Barèl and Barsdate, 1974) and probably does not contribute significantly to the available pool at any time. Some of the increase in available phosphorus recorded in this study may be accounted for by leaching of plant and fecal materials added to the surface as a result of a relatively high lemming population during the winter of 1976-1977.

R. Miller (pers. comm.) has suggested that the elevated phosphorus levels may be directly related to hydrolysis of accumulated polyphosphate bodies as microbial populations decrease and lyse.

CONCLUSIONS

(1) All apparent soil physical and/or chemical changes induced by the surface application of hydrocarbons must be interpreted with respect to the spatial variability of soil morphology in the experimental sites. 
(2) Pronounced changes in shrinkage, soil moisture and bulk density did not occur. However, a reduction in water infiltration rate was observed on hydrocarbon treated soils and is probably related to a decrease in the soil wetability as hydrophobic coats were formed around structural units.

(3) Thaw depth increased markedly in the first two summers after application. The effect however appeared to be weaker the third summer and was probably short term (less than 5 years duration).

(4) Exchangeable (available) cations generally decreased in abundance with increasing hydrocarbon application. Like the decrease in infiltration rate, this is probably the result of hydrophobic hydrocarbon residues, in this case blocking the exchange sites on organic and clay particles. This phenomenon was nearly of equal magnitude between the 5 and $12 \mathrm{l} / \mathrm{m}^{2}$ application.

(5) Soil reaction, although highly variable appeared to shift slightly toward neutrality. The shift was greatest at sites with the $121 / \mathrm{m}^{2}$ application rate. This condition probably favored the bacterial decomposers.

(6) Organic carbon generally increased on the hydrocarbon treated plots and will remain higher until microbial decomposition reduces it.

(7) Total sulfur was unaffected by the addition of crude oil - at least in volumes less than $12 \mathrm{l} / \mathrm{m}^{2}$.

(8) Available phosphorus increased significantly between 1976 and 1977 and may be related to release from organic residues through leaching or hydrolysis of microbial polyphosphates.

\section{ACKNOWLEDGEMENTS}

This manuscript has benefited from the reviews of Dr. T. C. Hutchinson and Dr. R. H. Miller. Ms. Nancy Grulke assisted in the field in 1975, Mr. Robert Antibus in 1976 and Ms. Heidi Diederichs in 1977.

\section{REFERENCES}

ABDALLA, A.A. and HOCKER, W. J. 1963. The effect of hexadecanol on water loss from soil and plants. Proceedings of the American Society of Horticultural Science. 83: 849-854.

ADAMS, R. S. JR., and ELLIS, R. JR. 1960. Some physical and chemical changes in the soil brought about by saturation with natural gas. Proceedings of the Soil Science Society of America. 24: 41-44.

BAREL, D. and BARSDATE, R. J. 1974. Phosphorus characterization of wet coastal tundra soils near Barrow, Alaska. United States Tundra Biome Data Report 74-15. 119p.

BROWN, J. and VEUM, A. K. 1974. Soil properties of the international tundra biome sites in A. J. Holding, O. W. Heal, S. F. Maclean, Jr. and P. W. Flanagan (eds.). Soil Organisms and Decomposition in Tundra. p. 27-48.

BROWN, J., EVERETT, K. R., WEBBER, P. J., MACLEAN, S. F. Jr. and MURRAY, D. F. (in press). The Barrow site. Chapter 1 in J. Brown, F. Bunnell, S. Maclean, P. Miller and L. Tieszen (eds). An Arctic Ecosystem: The Coastal Tundra of Northern Alaska. 
CARR, R. H. 1919. Vegetation growth in soils containing crude petroleum. Soil Science. 8: 67-68.

DENEKE, F. J., McCOWN, B. H., COYNE, P. I., RICHARD, W. and BROWN, J. 1975. Biological aspects of terrestrial oil spills - U.S.A. C.R.R.E.L. Oil Research in Alaska, 1970-1974. United States Army Cold Regions Research and Engineering Laboratory. Research Report 346. 66p.

EDIGAROVA, N. N. 1963. Behavior of organic substances of petroleum origin in the soil. Abstract in Commonwealth Bureau of Soil Science. 28: 478.

ELLIS, R. JR. and ADAMS, R. S. JR. 1961. Contamination of soils by petroleum hydrocarbons. Advances in Agronomy. 13: 197-216.

EVERETT, K. R. 1974. Principal soils and geomorphic units of the Barrow sites. United States Tundra Biome Data Report. 74-7. 45p.

GERSPER, P. L., ARKLEY, R. J., GLAUSER, R. and FLINT, P. S. 1974. Chemical and physical soil properties and their seasonal dynamics at the Barrow intensive site. United States Tundra Biome Data Report. 74-12. 89p.

HARPER, H. J. 1939. The effects of natural gas on the growth of microorganisms and the accumulation of nitrogen and organic matter in the soil. Soil Science. 48: 461-466.

HUTCHINSON, T. C. 1973. Preliminary studies on the effects of a simulated oil spill on Arctic terrestrial vegetation. Oil and the Canadian Environment. In D. Mackay and W. Harrison (eds.) Proceedings - Institute of Environmental Sciences and Engineering. University of Toronto, 142p.

HUTCHINSON, T. C. and HELlebuST, J. A. 1974. Oil spills and vegetation at Norman Wells, N.W.T. Report published by Environmental Social Program Northern Pipelines Task Force on Northern Oil Development, Rept. No. 73-43 129p.

MACKAY, D. and PHILLIPS, C. R. 1974. Chemical nature of northern crude oils. In D. Mackay, M. E. Charles and C. R. Phillips (eds.). The Physical Aspects of Crude Oil Spills on Northern Terrain. Environmental - Social Committee Northern Pipelines Task Force on Northern Oil Development Rept. No. 73-42. 213p.

MACKAY, D. 1975. The physical behaviour of oil spills on northern terrain. In Proceedings of Conference on the Environmental Effects of Oil and Saltwater Spills on Land. University of Calgary, Alberta, Canada: 81-110.

MACKAY, D. and MOHTADI, M. F. 1975. The area affected by oil spills on land. Canadian Journal of Chemical Engineering. 53: 140.

McFADDEN, T., JENKINS, T., COLLINS, C. JOHNSON, L., McCOWN, B. and SPARROW, E. 1977. Fate and effects of crude oil spills on permafrost terrain. United States Cold Regions and Engineering Laboratory. Special Report 77-44. 28p.

MILLER, O. K. 1975 and 1976. Oil persistence in tundra and its impact on the belowground ecosystem. Unpublished Annual Progress Reports prepared for the Energy Research and Development Administration. Contract E-(40-1)-4940.

NYBORG, M. and McGILL, W. B. 1975. Restoration of oil spills in forest soils. In Proceedings of Conference on the Environmental Effects of Oil and Saltwater Spills on Land. University of Calgary, Alberta, Canada: $277-290$

PLICE, M. J. 1948. Some effects of crude petroleum on soil fertility. Proceedings of Soil Science Society of America. 13: 413-416.

RICKWOOD, F. K. 1970. The Prudhoe Bay Field: in Geological Seminar on the North Slope of Alaska, Proceedings. American Association of Petroleum Geologists, Pacific Section. p. I-1 - I-11.

ROWELL, M. J. 1975. Restoration of oil spills on agricultural soils. In Proceedings of Conference on the Environmental Effects of Oil and Saltwater Spills on Land. University of Calgary, Alberta, Canada: 250-276.

SCHOLLENBERGER, C. J. 1930. Effect of leaking natural gas upon soils. Soil Science 29: 261-266.

TOOGOOD, J. A. 1977. Effects of oil spills on physical properties of soils. In Reclamation of Agricultural Soils After Oil Spills. Part I. Research. J. A. Toogood (ed.). Alberta Institute of Pedology Publication No. M-77-11. University of Alberta, Edmonton, Alberta: 108-115.

— ROWELL, M. J. and NYBORG, M. 1977. Reclamation experiments in the field. The Reclamation of Agricultural Soils After Oil Spills. Part I Research. J. A. Toogood (ed.) Alberta Institute of Pedology Publication No. M-77-11. 
APPENDIX 1. 3 year ranges in some significant physical and chemical properties in tundra soils amended with crude oil. *indicates a two year period.

\begin{tabular}{|c|c|c|c|c|c|}
\hline \multirow[b]{2}{*}{ Variable } & \multirow[b]{2}{*}{ Plot } & \multirow{2}{*}{$\begin{array}{l}\text { Depth } \\
\text { in } \mathrm{cm}\end{array}$} & \multicolumn{3}{|c|}{ Treatments } \\
\hline & & & Control & $5 \mathrm{l} / \mathrm{m}^{2}$ & $12 \mathrm{l} / \mathrm{m}^{2}$ \\
\hline \multirow{12}{*}{$\begin{array}{l}\text { Soil Moisture } \\
\text { Vol. \% }\end{array}$} & & $0-2$ & $11-91$ & $57-92$ & $46-88$ \\
\hline & Basin & $2-4$ & $66-89$ & $61-99$ & $61-93$ \\
\hline & & & $63-91$ & $64-87$ & $61-88$ \\
\hline & & $0-2$ & $39-81$ & $27-75$ & $39-78$ \\
\hline & Rim & $2-4$ & $55-77$ & $47-75$ & $40-75$ \\
\hline & & $4-8$ & $47-74$ & $43-71$ & $46-69$ \\
\hline & & $0-2$ & $13-85$ & $18-85$ & $32-67$ \\
\hline & Trough & $2-4$ & $23-88$ & $45-90$ & $34-86$ \\
\hline & & $4-8$ & $52-88$ & $56-80$ & $34-85$ \\
\hline & & $0-2$ & $15-66$ & $11-56$ & $17-59$ \\
\hline & High & $2-4$ & $21-65$ & $21-69$ & $28-69$ \\
\hline & Center & $4-8$ & $27-66$ & $31-67$ & $36-64$ \\
\hline \multirow{12}{*}{$\begin{array}{c}\text { Shrinkage } \\
\%\end{array}$} & & $0-2$ & $26-71$ & $19-54$ & $23-46$ \\
\hline & Basin & $2-4$ & $26-59$ & $29-62$ & $30-70$ \\
\hline & & $4-8$ & $27-53$ & $27-61$ & $33-58$ \\
\hline & & $0-2$ & $20-57$ & $22-54$ & $20-54$ \\
\hline & Rim & $2-4$ & $23-55$ & $8-53$ & $24-65$ \\
\hline & & $4-8$ & $15-50$ & $17-60$ & $20-73$ \\
\hline & & $0-2$ & $16-56$ & $7-59$ & $17-51$ \\
\hline & Trough & $2-4$ & $19-59$ & $19-56$ & $23-56$ \\
\hline & & $4-8$ & $32-60$ & $24-51$ & $27-59$ \\
\hline & & $0-2$ & $10-36$ & $8-46$ & $8-40$ \\
\hline & High & $2-4$ & $15-44$ & $0-48$ & $8-47$ \\
\hline & Center & $4-8$ & $17-54$ & $10-38$ & $12-59$ \\
\hline \multirow{12}{*}{$\begin{array}{l}\text { Exchangeable } \\
\text { Potassium } \\
\text { in meq/100 } \mathrm{g}\end{array}$} & & $0-2$ & $0.64-1.5$ & $0.26-0.36$ & $0.22-0.40$ \\
\hline & Basin & $2-4$ & $0.37-0.69$ & $0.27-0.34$ & $0.26-0.38$ \\
\hline & & $4-8$ & $0.15-0.28$ & $0.11-0.13$ & $0.10-0.19$ \\
\hline & & $0-2$ & $0.52-39.1$ & $0.34-0.45$ & $0.36-0.51$ \\
\hline & Rim & $2-4$ & $0.20-6.6$ & $0.26-0.27$ & $0.17-0.26$ \\
\hline & & $4-8$ & $0.10-7.8$ & $0.16-0.20$ & $0.13-0.21$ \\
\hline & & $0-2$ & $0.56-3.5$ & $0.46-2.2$ & $0.38-1.3$ \\
\hline & Trough & $2-4$ & $0.83-1.7$ & $0.74-0.99$ & $0.47-1.3$ \\
\hline & & $4-8$ & $0.22-0.74$ & $0.22-0.45$ & $0.36-1.0$ \\
\hline & & $0-2$ & $0.55-1.44$ & MSG-0.96 & $0.43-0.48$ \\
\hline & High & $2-4$ & $0.34-0.73$ & $0.39-0.40$ & $0.22-0.40$ \\
\hline & Center & $4-8$ & $0.26-0.51$ & $0.39-0.46$ & $0.16-0.37$ \\
\hline
\end{tabular}


Appendix I (cont 'd)

\begin{tabular}{|c|c|c|c|c|c|}
\hline \multirow[b]{2}{*}{ Variable } & \multirow[b]{2}{*}{ Plot } & \multirow{2}{*}{$\begin{array}{l}\text { Depth } \\
\text { in } \mathrm{cm}\end{array}$} & \multicolumn{3}{|c|}{ Treatments } \\
\hline & & & Control & $51 / \mathrm{m}^{2}$ & $12 \mathrm{l} / \mathrm{m}^{2}$ \\
\hline \multirow[t]{4}{*}{$\begin{array}{l}\text { Dry Wt. } \\
\text { bulk density } \\
\text { in } \mathrm{g} / \mathrm{cm}^{3}\end{array}$} & Basin & $\begin{array}{l}0-2 \\
2-4 \\
4-8\end{array}$ & $\begin{array}{l}0.24-0.49 \\
0.31-0.64 \\
0.46-0.63\end{array}$ & $\begin{array}{l}0.31-0.61 \\
0.35-0.63 \\
0.43-0.72\end{array}$ & $\begin{array}{l}0.36-0.59 \\
0.50-0.96 \\
0.47-0.80\end{array}$ \\
\hline & Rim & $\begin{array}{l}0-2 \\
2-4 \\
4-8\end{array}$ & $\begin{array}{l}0.14-0.75 \\
0.44-0.92 \\
0.44-0.83\end{array}$ & $\begin{array}{l}0.17-0.81 \\
0.15-1.27 \\
0.31-0.91\end{array}$ & $\begin{array}{l}0.18-0.85 \\
0.37-0.80 \\
0.50-0.88\end{array}$ \\
\hline & Trough & $\begin{array}{l}0-2 \\
2-4 \\
4-8\end{array}$ & $\begin{array}{l}0.11-0.29 \\
0.12-0.37 \\
0.34-0.92\end{array}$ & $\begin{array}{l}0.14-0.31 \\
0.13-0.28 \\
0.18-0.66\end{array}$ & $\begin{array}{l}0.26-0.58 \\
0.16-0.45 \\
0.32-0.81\end{array}$ \\
\hline & $\begin{array}{l}\text { High } \\
\text { Center }\end{array}$ & $\begin{array}{l}0-2 \\
2-4 \\
4-8 \\
\end{array}$ & $\begin{array}{l}0.14-0.54 \\
0.46-0.85 \\
0.37-0.68 \\
\end{array}$ & $\begin{array}{l}0.36-0.71 \\
0.30-0.76 \\
0.44-0.71\end{array}$ & $\begin{array}{l}0.37-0.88 \\
0.43-1.13 \\
0.50-0.91\end{array}$ \\
\hline \multirow[t]{4}{*}{$\begin{array}{c}\text { Organic } \\
\text { Carbon } \\
\%\end{array}$} & Basin & $\begin{array}{l}0-2 \\
2-4 \\
4-8 \\
\end{array}$ & $\begin{array}{l}37-43 \\
36-45 \\
35-49\end{array}$ & $\begin{array}{l}39-57 \\
38-45 \\
34-42\end{array}$ & $\begin{array}{l}25-60 \\
39-47 \\
35-41\end{array}$ \\
\hline & Rim & $\begin{array}{l}0-2 \\
2-4 \\
4-8\end{array}$ & $\begin{array}{l}37-42 \\
31-40 \\
15-43 \\
\end{array}$ & $\begin{array}{l}26-33 \\
23-29 \\
24-32 \\
\end{array}$ & $\begin{array}{l}39-62 \\
29-49 \\
21-50\end{array}$ \\
\hline & Trough & $\begin{array}{l}0-2 \\
2-4 \\
4-8\end{array}$ & $\begin{array}{l}37-42 \\
38-43 \\
21-54\end{array}$ & $\begin{array}{l}40-67 \\
38-50 \\
20-55\end{array}$ & $\begin{array}{l}41-70 \\
38-65 \\
21-52\end{array}$ \\
\hline & $\begin{array}{c}\text { High } \\
\text { Center }\end{array}$ & $\begin{array}{l}0-2 \\
2-4 \\
4-8\end{array}$ & $\begin{array}{l}19-31 \\
18-28 \\
18-26 \\
\end{array}$ & $\begin{array}{l}18-45 \\
20-27 \\
18-24\end{array}$ & $\begin{array}{r}8-41 \\
16-33 \\
19-33 \\
\end{array}$ \\
\hline \multirow[t]{4}{*}{$\begin{array}{l}\text { Soil pH } \\
1: 5 \text { soil- } \\
\text { water }\end{array}$} & Basin & $\begin{array}{l}0-2 \\
2-4 \\
4-8\end{array}$ & $\begin{array}{l}4.6-5.1 \\
4.8-5.3 \\
4.7-5.5\end{array}$ & $\begin{array}{l}4.5-5.5 \\
4.6-5.7 \\
4.9-5.7\end{array}$ & $\begin{array}{l}5.0-5.6 \\
4.9-5.5 \\
4.7-5.6\end{array}$ \\
\hline & $\operatorname{Rim}$ & $\begin{array}{l}0-2 \\
2-4 \\
4-8\end{array}$ & $\begin{array}{l}3.9-5.3 \\
4.4-5.4 \\
4.4-5.5\end{array}$ & $\begin{array}{l}4.5-5.5 \\
3.9-5.2 \\
4.5-5.4\end{array}$ & $\begin{array}{l}4.7-5.4 \\
4.6-5.1 \\
4.4-5.1\end{array}$ \\
\hline & Trough & $\begin{array}{l}0-2 \\
2-4 \\
4-8\end{array}$ & $\begin{array}{l}5.0-5.7 \\
5.0-5.7 \\
5.0-6.0\end{array}$ & $\begin{array}{l}4.3-5.6 \\
4.9-5.8 \\
4.9-5.7\end{array}$ & $\begin{array}{l}4.1-6.2 \\
5.0-5.9 \\
4.8-5.5\end{array}$ \\
\hline & $\begin{array}{c}\text { High } \\
\text { Center }\end{array}$ & $\begin{array}{l}0-2 \\
2-4 \\
4-8\end{array}$ & $\begin{array}{l}3.9-5.0 \\
4.0-4.7 \\
4.0-4.9\end{array}$ & $\begin{array}{l}3.4-5.1 \\
4.0-4.7 \\
3.9-4.6\end{array}$ & $\begin{array}{l}4.1-5.7 \\
3.9-5.4 \\
4.1-5.5\end{array}$ \\
\hline
\end{tabular}


Appendix I (cont'd)

\begin{tabular}{|c|c|c|c|c|c|}
\hline \multirow[b]{2}{*}{ Variable } & \multirow[b]{2}{*}{ Plot } & \multirow{2}{*}{$\begin{array}{l}\text { Depth } \\
\text { in } \mathrm{cm}\end{array}$} & \multicolumn{3}{|c|}{ Treatments } \\
\hline & & & Control & $5 \mathrm{l} / \mathrm{m}^{2}$ & $12 \mathrm{l} / \mathrm{m}^{2}$ \\
\hline \multirow{12}{*}{$\begin{array}{l}\text { Exchangeable } \\
\text { Calcium } \\
\text { in meq } / 100 \mathrm{~g}\end{array}$} & & $0-2$ & $13.1-16.6$ & $8.3-9,7$ & $8.1-10.8$ \\
\hline & Basin & $2-4$ & $13.9-15.0$ & $14.2-15.7$ & $14.8-15.3$ \\
\hline & & $4-8$ & $11.7-13.3$ & $11.3-12.8$ & $11.2-11.3$ \\
\hline & & $0-2$ & $12.3-21.8$ & $9.0-14.7$ & $6.7-11.0$ \\
\hline & Rim & $2-4$ & $10.9-21.6$ & $7.0-12.8$ & $4.9-7.9$ \\
\hline & & $4-8$ & $5.9-23.3$ & $8.6-12.5$ & 5.4- 8.9 \\
\hline & & $0-2$ & $9.8-36.2$ & $8.0-16.5$ & $7.2-10.8$ \\
\hline & Trough & $2-4$ & $20.4-36.2$ & $17.0-23.1$ & $14.3-25.0$ \\
\hline & & $4-8$ & $10.6-32.9$ & $8.3-17.2$ & $12.8-30.6$ \\
\hline & High & $0-2$ & $6.0-10.4$ & 3.1-MSG & $4.5-8.9$ \\
\hline & Center & $2-4$ & $3.3-6.8$ & $4.3-5.5$ & $8.0-20.6$ \\
\hline & & $4-8$ & $2.7-5.0$ & $3.4-5.7$ & $5.7-14.8$ \\
\hline \multirow{12}{*}{$\begin{array}{l}\text { Exchangeable } \\
\text { Magnesium } \\
\text { in meq } / 100 \mathrm{~g}\end{array}$} & & $0-2$ & $9.8-12.3$ & $5.3-7.2$ & $5.1-7.2$ \\
\hline & Basin & $2-4$ & $9.1-10.5$ & $9.7-10.7$ & $9.5-10.0$ \\
\hline & & $4-8$ & $7.4-10.0$ & $8.9-9.4$ & $7.8-8.7$ \\
\hline & & $0-2$ & $8.3-14.9$ & $6.3-11.1$ & $6.0-9.9$ \\
\hline & Rim & $2-4$ & $7.2-13.0$ & $5.6-8.2$ & $4.3-7.2$ \\
\hline & & $4-8$ & $4.9-12.3$ & $6.5-8.2$ & $4.7-8.0$ \\
\hline & & $0-2$ & $5.7-15.7$ & $4.4-9.9$ & $3.5-6.9$ \\
\hline & Trough & $2-4$ & $12.2-20.0$ & $10.4-12.6$ & $7.5-11.8$ \\
\hline & & $4-8$ & $7.2-12.6$ & $5.7-10.1$ & $8.4-12.7$ \\
\hline & High & $0-2$ & $3.0-5.8$ & 4.1-MSG & $2.6-4.5$ \\
\hline & Center & $2-4$ & $1.0-3.5$ & $3.1-3.3$ & $2.0-3.4$ \\
\hline & & $4-8$ & $0.8-2.4$ & $2.3-3.1$ & $2.5-4.7$ \\
\hline \multirow{12}{*}{$\begin{array}{c}\text { Total } \\
\text { Sulfur } \\
\%\end{array}$} & & $0-2$ & $0.16-0.32$ & $0.09-0.33$ & $0.09-0.31$ \\
\hline & Basin & $2-4$ & $0.09-0.24$ & $0.09-0.28$ & $0.10-0.25$ \\
\hline & & $4-8$ & $0.02-0.17$ & $0.05-0.20$ & $0.08-0.17$ \\
\hline & & $0-2$ & $0.09-0.21$ & $0.10-0.23$ & $0.07-0.23$ \\
\hline & Rim & $2-4$ & $0.07-0.23$ & $0.07-0.30$ & $0.04-0.25$ \\
\hline & & $4-8$ & $0.04-0.21$ & $0.08-0.22$ & $0.01-0.18$ \\
\hline & & $0-2$ & $0.11-0.37$ & $0.15-0.29$ & $0.10-0.32$ \\
\hline & Trough & $2-4$ & $0.13-0.39$ & $0.16-0.28$ & $0.14-0.32$ \\
\hline & & $4-8$ & $0.13-0.41$ & $0.10-0.26$ & $0.15-0.28$ \\
\hline & High & $0-2$ & $0.04-0.12$ & $0.02-0.07$ & $0.02-0.25$ \\
\hline & Center & $2-4$ & $0.01-0.12$ & $0.02-0.21$ & $0.04-0.17$ \\
\hline & & $4-8$ & $0.01-0.12$ & $0.01-0.10$ & $0.03-0.23$ \\
\hline
\end{tabular}


Appendix I (cont 'd)

\begin{tabular}{|c|c|c|c|c|c|}
\hline \multirow[b]{2}{*}{ Variable } & \multirow[b]{2}{*}{ Plot } & \multirow{2}{*}{$\begin{array}{l}\text { Depth } \\
\text { in } \mathrm{cm}\end{array}$} & \multicolumn{3}{|c|}{ Treatments } \\
\hline & & & Control & $5 \mathrm{l} / \mathrm{m}^{2}$ & $12 \mathrm{l} / \mathrm{m}^{2}$ \\
\hline \multirow{12}{*}{$\begin{array}{c}\text { Available } \\
\text { Phosphorus* } \\
\text { in } \mu \mathrm{g} / \mathrm{g} \text { dry wt. }\end{array}$} & & $0-2$ & $1.3-7.4$ & $2.0-20.0$ & $1.2-27.8$ \\
\hline & Basin & $2-4$ & $1.3-31.0$ & $0.8-19.6$ & $1.0-9.9$ \\
\hline & & $4-8$ & $0.8-18.5$ & $0.5-13.5$ & $0.7-22.2$ \\
\hline & & $0-2$ & $1.3-34.1$ & $2.0-7.4$ & $1.3-38.7$ \\
\hline & $\operatorname{Rim}$ & $2-4$ & $1.3-34.5$ & $1.1-19.4$ & $1.1-22.7$ \\
\hline & & $4-8$ & $1.2-22.7$ & $1.0-3.8$ & $1.1-17.9$ \\
\hline & & $0-2$ & $4.6-20.3$ & $3.4-47.7$ & $0.9-76.6$ \\
\hline & Trough & $2-4$ & $1.5-6.31$ & $3.4-12.9$ & $3.2-19.4$ \\
\hline & & $4-8$ & $0.2-8.4$ & $2.7-21.0$ & $0.6-26.5$ \\
\hline & High & $0-2$ & $0.5-16.8$ & $2.6-13.5$ & $1.6-28.0$ \\
\hline & Center & $2-4$ & $0.2-10.9$ & $1.1-8.1$ & $0.8-20$ \\
\hline & & $4-8$ & $0.2-5.3$ & $1.1-6.5$ & $0.7-22.7$ \\
\hline
\end{tabular}

